\title{
A MODELING STUDY OF OPERATING CONDITIONS AND DIFFERENT SUPPORTS ON Fe-Co-Ce NANOCATALYST AND OPTIMIZING OF LIGHT OLEFINS SELECTIVITY IN THE FISCHER-TROPSCH SYNTHESIS
}

\author{
Tahereh Taherzadeh Lari ${ }^{1,} \otimes$, Ali Akbar Mirzaei ${ }^{1}, H_{0}$ Hoin Atashi², \\ Hamid Reza Bozorgzadeh ${ }^{3}$
}

https://doi.org/10.23939/chcht15.02.170

\begin{abstract}
This study demonstrates the effect of operating conditions (Red-GHSV, inlet $\mathrm{H}_{2} / \mathrm{CO}$, Oprat-GHSV) and the effect of Fe-Co-Ce nanocatalyst support. A statistical model using the response surface methodology (RSM) was applied with the target of achieving higher olefins selectivity in Fischer-Tropsch synthesis, which indicates the interaction effects of factors. The conditions under which three objectives optimization for maximizing olefins and minimizing paraffins and methane were determined. Synthesized nanocatalysts with various supports were characterized by XRD, SEM and TPR techniques.
\end{abstract}

Keywords: modeling study, operating conditions, Fe-Co-Ce nanocatalyst, support, optimization, Fischer-Tropsch synthesis.

\section{Introduction}

Fischer-Tropsch synthesis has attracted a novel interest due to depletion of crude oil and quick incrementing of universal demand to liquid fuels in the recent years. The Fischer-Tropsch synthesis (FT) is defined as the transformation of syngas to hydrocarbon products, which can either be liquid fuels such as gasoline, diesel, jet fuel or be building block of chemicals such as lower olefins $[1,2]$. Comparably, some studies demonstrated that syngas based fuels are more environmentally friendly than petroleum based fuels due to sulfur and nitrogen free [3]. In the last twenty years, research on

\footnotetext{
${ }^{1}$ Department of Chemistry, Faculty of Science, University of Sistan and Baluchestan,

P.O. Box 98135-674, Zahedan, Iran

${ }^{2}$ Department of Chemical Engineering, Faculty of Engineering,

University of Sistan and Baluchestan,

P.O. Box 98164-161, Zahedan, Iran

${ }^{3}$ Catalyst Division, Research Institute of Petroleum Industry (RIPI),

Tehran, Iran

\tzd.tahereh@yahoo.com,lari.tahereh@gmail.com

(C) Lari T., Mirzaei A., Atashi H., Bozorgzadeh H., 2021
}

ceria-based materials has been raised quickly. A prominent part of this effort devotes to $\mathrm{M}-\mathrm{CeO}_{2}$ and other similar catalyst systems including transition metals with rare earth oxides and ceria containing mixed oxides [4]. The function of ceria in an industrial process has a significant role at formulation of a catalyst. This finding causes activity and selectivity of catalyst trending towards rising olefins and decreasing methane as a noteworthy achievement. The Fe-Co bimetallic catalysts containing other metals as a promoter were found to have higher activity and selectivity than monometallic catalysts. Moreover, bimetallic catalysts indicate various distributions of products. Some researchers studied the effects of preparation and operating conditions on bimetallic catalysts $[5,6]$. The vital variables to FT process, which influence lifetime, activity and selectivity of the product, are operating conditions such as feed gas composition $\mathrm{H}_{2} / \mathrm{CO}$, and gas resistance time (GHSV). As well as, changing in support type affects the product selectivity of FT process and catalyst activity. It is reported that the product selectivity increases in the series of $\mathrm{Al}_{2} \mathrm{O}_{3}<\mathrm{SiO}_{2}<\mathrm{TiO}_{2}$ support types [7]. Response surface methodology (RSM) was applied for modeling and optimizing the operating variables and various supports in the Fischer-Tropsch synthesis. The statistical analysis of this work comparing with the works where a model was not represented [8,9] has beneficial importance of illustrating effects of each variables and effect of their interaction. To the best of the authors' knowledge, no study has been reported regarding the operating conditions and the effect of supports on ternary $\mathrm{Fe}-\mathrm{Co}-\mathrm{Ce}$ nanocatalyst synthesized using a solvothermal method. A statistical model was used for investigating the selectivity of response and optimizing the products in order to maximize olefins in a fixed-bed reactor. The effect of different supports on particle size, crystal structure, morphology and reducibility was examined by XRD, SEM and TPR techniques. 


\section{Experimental}

\subsection{Materials}

The chemical reagents including cerium(III) nitrate hexahydrate $\left(\mathrm{Ce}\left(\mathrm{NO}_{3}\right)_{3} \cdot 6 \mathrm{H}_{2} \mathrm{O}, 99 \%\right)$, cobalt(II) nitrate hexahydrate $\left(\mathrm{Co}\left(\mathrm{NO}_{3}\right)_{2} \cdot 6 \mathrm{H}_{2} \mathrm{O}, 99 \%\right)$, iron(II) nitrate nonahydrate $\left(\mathrm{Fe}\left(\mathrm{NO}_{3}\right)_{3} \cdot 9 \mathrm{H}_{2} \mathrm{O}, 99 \%\right)$, toluene $\left(\mathrm{C}_{7} \mathrm{H}_{8}\right.$, 99\%), ethanol $\left(\mathrm{C}_{2} \mathrm{H}_{5} \mathrm{OH}, 99 \%\right), \mathrm{MgO}(99 \%), \mathrm{TiO}_{2}(99 \%)$, $\mathrm{SiO}_{2}(99 \%)$ and zeolite $(99 \%)$ were supplied by Merck. Oleylamine $\left(\mathrm{C}_{18} \mathrm{H}_{37} \mathrm{~N}, 70 \%\right)$ was purchased from Aldrich. All reagents were used without further purification.

\subsection{Nanocatalyst Synthesis}

Iron-cobalt-cerium nanocatalyst was prepared using a solvothermal procedure. The preparation method can be briefly described as follows: $0.38 \mathrm{~g}(0.94 \mathrm{mmol})$ of iron nitrate, $0.32 \mathrm{~g}(0.91 \mathrm{mmol})$ of cobalt nitrate, and $0.125 \mathrm{~g}$ $(0.25 \mathrm{mmol})$ of cerium nitrate were added to $50 \mathrm{ml}$ of toluene containing $10 \mathrm{~g}(37.4 \mathrm{mmol})$ of oleylamine. Then the same amount of support (10 wt \%) was added to each catalyst. The mixture was stirred with a magnet vigorously for $1 \mathrm{~h}$ at room temperature. Then the resulting mixture solution was transferred into a $80 \mathrm{ml}$ Teflon-lined autoclave and heated to $453 \mathrm{~K}$. The autoclave was sealed and maintained at the given temperature for $18 \mathrm{~h}$ before it was allowed to cool down to room temperature. The formed nanoparticles were precipitated into an excess ethanol and further isolated from each other by centrifuging. Finally the resulting nanoparticles were transferred to an oven to be dried at $373 \mathrm{~K}$ and calcinated at $773 \mathrm{~K}$ in air atmosphere for 4 and $5 \mathrm{~h}$, respectively.

\subsection{Characterization}

\subsubsection{X-ray diffraction (XRD)}

The X-ray diffraction (XRD) measurements of iron-cobalt-cerium three metals oxide for confirmation of phase and structure were carried out using EXPERT PHILIPS diffractometer equipped with $\mathrm{Cu}-\mathrm{K} \alpha$ radiation (wavelength $1.54046 \AA$ ) at $40 \mathrm{kV}$ and $30 \mathrm{~mA}$. The XRD data were acquired at room temperature with a step-scan interval of $0.0200,0.35 \mathrm{~s}$ per step and angular extension of 10-1100 (29). The XRD measurement error coefficient was $10 \%$. The determination of the mean crystalline diameter was performed on the (111) peak using the Scherrer equation:

$$
D=\frac{K \lambda}{\beta \cos \theta}
$$

Where $D$ is the mean particle size, nm; $\lambda$ is the wavelength of the incident X-ray, $\AA$; $\beta$ is the full-width at half maximum; $\theta$ is the diffraction angle, grad.

\subsubsection{Scanning electron microscopy (SEM)}

The morphology and homogeneity of samples were determined using a scanning electron microscope (SEM MIRA II LMU/TESCAN) with an accelerating voltage of $1500 \mathrm{kV}$. For SEM analysis, the sample was dispersed in ethanol on an aluminum foil wrapped with the aluminum stub. The samples were dried in air and the stub was mounted in the SEM chamber. The particle size was measured at a resolution of $200 \mathrm{~nm}$ with a magnification of 15,000 .

\subsubsection{Temperature-programmed reduction (TPR)}

Different mixed oxide samples were subjected to a temperature-programmed reduction (TPR) with hydrogen, which incorporated a thermal conductivity detector (TCD). The sample $(0.05 \mathrm{~g})$ was loaded in a quartz TPR cell and experiments were carried out at a heating rate of $5 \mathrm{~K} / \mathrm{min}$. The reactive gas composition was $\mathrm{H}_{2}(5 \mathrm{vol} \%)$ in argon and the flow rate was fixed at $20 \mathrm{ml} / \mathrm{min}$ (STP). The total reactive gas consumption was measured during TPR analysis. After cooling sample to $313 \mathrm{~K}$ in an argon flow, the TPR measurements were carried out following activation. Then the sample was maintained at $323 \mathrm{~K}$ under the argon flow in order to remove the remaining adsorbed oxygen until the TCD signal returned to the baseline. Subsequently, the TPR experiments were performed up to $1123 \mathrm{~K}$.

\subsection{Research Catalytic Micro-Reactor Setup}

The Fischer-Tropsch synthesis was carried out in a stainless fixed-bed micro-reactor with an inner diameter of $12 \mathrm{~mm}$. The catalyst $(1.0 \mathrm{~g})$ was well dispersed with asbestos and loaded in the center of the reactor where the thermocouple is. Three mass flow controllers (Model 5850E, Brooks Instrument, Hatfield, PA, USA) were used to adjust the flow rate of the inlet gases containing $\mathrm{CO}, \mathrm{H}_{2}$ and $\mathrm{N}_{2}$ (with $99.99 \%$ purity) automatically. A mixture of $\mathrm{CO}$ and $\mathrm{H}_{2}\left(\mathrm{H}_{2} / \mathrm{CO}=1\right.$, flow rate of each gas $\left.=30 \mathrm{ml} \cdot \mathrm{min}^{-1}\right)$ was subsequently directed into the reactor, which was placed inside a tubular furnace (Figs. 1, 2, Model ATU 150-15, Atbin). The reaction temperature was controlled by a digital program controller (DPC) and visually monitored by a computer through a thermocouple inserted into the catalytic bed. Before the reaction started, the catalyst was prereduced under $200 \mathrm{kPa}$ pressure and $\mathrm{H}_{2}$ flow (with a flow rate of $30 \mathrm{ml} \cdot \mathrm{min}^{-1}$ ) at $673 \mathrm{~K}$ for $48 \mathrm{~h}$. In each test, $1.0 \mathrm{~g}$ of catalyst was loaded and all data were collected after $24 \mathrm{~h}$ in order to ensure that the steady state condition was attained. 


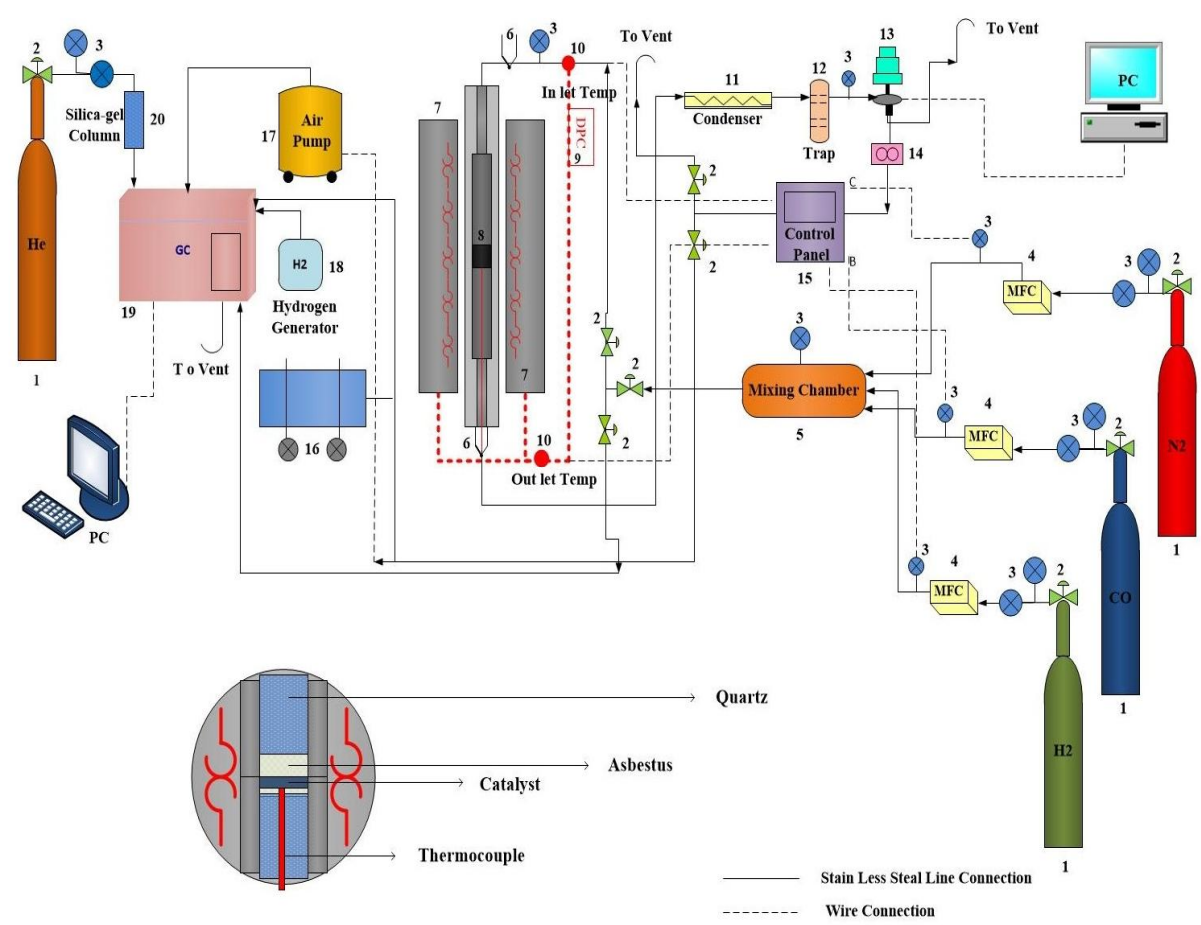

Fig. 1. The experimental setup of fixed bed reactor (FBR) for Fischer-Tropsch synthesis over iron-cobalt-cerium nanocatalyst. 1 - gas cylinders, 2 - valve, 3 - pressure gauge, 4 - mass flow controller (MFC), 5 - mixing chamber, 6 - thermocouple, 7 - tubular furnace, 8 - fix bed reactor and catalyst bed (reaction zone), 9 - temperature digital program controller (DPC), 10 - resistance temperature detector, 11 - condenser, 12 - trap, 13 - back pressure regulator (BPR), 14 - flow meter, 15 - control panel, 16 - electrical motor, 17 - air pump, 18 - hydrogen generator, 19 - gas chromatograph, 20 - silica-gel column

\subsection{Catalytic Selectivity Measurements}

The Fischer-Tropsch synthesis was performed at $\mathrm{GHSV}=3600 \mathrm{~h}^{-1}, \mathrm{H}_{2} / \mathrm{CO}=1: 1, P=200 \mathrm{kPa}, T=573 \mathrm{~K}$. In order to avoid the deactivation effect, the fresh catalyst was loaded under every operating condition. An automatic backpressure regulator was used for adjusting and modifying the pressure range via the TESCOM software. Reactant and product streams were analyzed by on-line gas chromatography (Thermo ONIX UNICAM PROGC+), which was equipped with two thermal conductivity detectors (TCD) and one flame ionization detector (FID) with the ability of analysis a broad variety of gaseous hydrocarbon mixtures. One TCD was used for analysis of hydrogen $\left(\mathrm{H}_{2}\right)$ and another one was used for all permanent gases such as $\mathrm{N}_{2}, \mathrm{O}_{2}$ and $\mathrm{CO}$. Not only the analysis of hydrocarbons by FID was done, but the analysis of non-condensable gases, methane, and $\mathrm{C}_{8}$ hydrocarbons was applied too. The contents of the sample loop were injected automatically into an alumina capillary column. Helium $(\mathrm{He})$ was applied as a carrier gas for achieving optimum sensitivity. The calibration was done by various mixtures including $\mathrm{CH}_{4}, \mathrm{C}_{2} \mathrm{H}_{4}, \mathrm{C}_{2} \mathrm{H}_{6}, \mathrm{C}_{3} \mathrm{H}_{6}$, $\left.\mathrm{C}_{3} \mathrm{H}_{8}, \quad n-\mathrm{C}_{4} \mathrm{H}_{10}, \quad i-\mathrm{C}_{4} \mathrm{H}_{10}, \quad n-\mathrm{C}_{5} \mathrm{H}_{12}\right)$, however pure compounds were obtained from Iran Tarkib Gas Alv and Company. The operating condition and obtained data of each experiment are presented below. The $\mathrm{CO}$ conversion $(\%)$ is calculated according to the formula (2):

$$
\mathrm{CO} \text { converion }=\frac{\left(\text { Moles of } \mathrm{CO}_{\text {in }}\right)-\left(\text { Moles of } \mathrm{CO}_{\text {out }}\right)}{\left(\text { Moles of } \mathrm{CO}_{\text {in }}\right)} \cdot 100
$$

\subsection{Statistical Analysis}

The activity and selectivity of the synthesized nanocatalysts towards products in Fischer-Tropsch synthesis are affected by many operating conditions and different support type. In this study, the effects of $\mathrm{H}_{2} / \mathrm{CO}$ inlet molar ratio, reduction GHSV (Red-GHSV), operating GHSV (Oprat-GHSV), and various supports on the selectivity of three products including olefins $\mathrm{C}_{2}-\mathrm{C}_{4}$, paraffins $\mathrm{C}_{2}-\mathrm{C}_{4}$, and methane $\mathrm{C}_{1}$ were investigated by response surface methodology (RSM). It is a set of statistical and mathematical techniques in order to utilize, improve and optimize a model via the impact on multiple factors using the design experiment method (DoE) [10]. The RSM is widely used in industry, where several input variables strongly affect the characteristic of the product or process, which called response. The most important advantage of RSM method compared to illustrating the results without statistic approach is designing, formulating of products, and predicting the interaction effects of involved factors. The RSM technique can suggest a model according to experimental and predictable data due to 
achieving the most desirable model for response by adjusting the factors. A model for desired response with several independent variables was obtained by applying DoE and regression analysis. In this study, a polynomial regression model was used to achieve appropriate correlation between experimental and desired response as the second order selectivity model of the product, which was employed as follows:

$$
f=t_{0}+\sum_{i=1}^{n} t_{i} x_{i}+\sum_{i=1}^{n} t_{i i} x_{i}^{2}+\sum_{i j}^{n} t_{i j} x_{i} x_{j} \pm \varepsilon
$$

where $f$ is the response surface; $t$ represents the coefficient of regression; $x$ is a variable (e.g. in this study variables are Red-GHSV, Oprat-GHSV, $\mathrm{H}_{2} / \mathrm{CO}$, and Type-support); $n$ is the number of experiments. The accuracy of regression model can be verified by coefficients $R^{2}$ and $R_{a d j}^{2}$ :

$$
\begin{gathered}
R^{2}=\frac{S S_{R}}{S S_{R}+S S_{E}} \\
R_{a d j}^{2}=1-\frac{\left(1-R^{2}\right)(n-1)}{n-p}
\end{gathered}
$$

The significance of regression coefficient is verified by $P$-values, which is not sufficient enough and should be lower than 0.05 . As well as for this purpose the other values such as $T$-value and $S_{E}$ coefficients are reported. The $P$-value has a reverse relation with $T$-value. The higher the $P$-value is the lower the $T$-value will be.

\section{Results and Discussion}

\subsection{Effect of Different Supports}

The use of support has some profits, including a stabilizing metal dispersion, increasing the availability of the number of surface metal atoms for catalysis, and improving the friction resistance. It was reported that the more reducible oxide supports is, the more extensive metal support interactions achieve [11]. A strong interaction between metal-support results in an electron exchange of a partially reduced support, therefore a suppression of hydrogen occurs on a metal. The activity of catalyst is affected by the support nature indirectly. In this work the effect of different supports such as $\mathrm{MgO}$, zeolite,
$\mathrm{TiO}_{2}$ and $\mathrm{SiO}_{2}$ on selectivity of Fe-Co-Ce nanocatalyst under operating conditions $\left(\mathrm{GHSV}=3600 \mathrm{~h}^{-1}, \mathrm{H}_{2} / \mathrm{CO}=\right.$ $=1: 1, P=200 \mathrm{kPa}, T=573 \mathrm{~K}$ ) was investigated.

\subsection{Characterization of Nanocatalysts}

\subsubsection{Crystal structure (XRD)}

The XRD patterns of the synthesized nanocatalyst with different supports are indicated in Fig. 2. In these samples the cubic structures of $\mathrm{CeO}_{2}$ (card no. 34-394), $\mathrm{Co}_{3} \mathrm{O}_{4}$ (card no. 9-418), and rhombohedral structure of $\mathrm{Fe}_{2} \mathrm{O}_{3}$ (card no. 33-664) are detected. The significant Bragg reflections can be indexed to the structures of $\mathrm{CeO}_{2}, \quad \mathrm{Co}_{3} \mathrm{O}_{4}$, and $\mathrm{Fe}_{2} \mathrm{O}_{3}$ with the corresponding diffraction peaks of (111), (311) and (104) respectively. Furthermore, the XRD data are used to determine the average crystalline size of samples, which are shown in Table 1. The average crystallite size of synthesized samples is estimated to be around $2.7-8.2 \mathrm{~nm}$. The smaller particle size is achieved for $\mathrm{SiO}_{2}$ support.

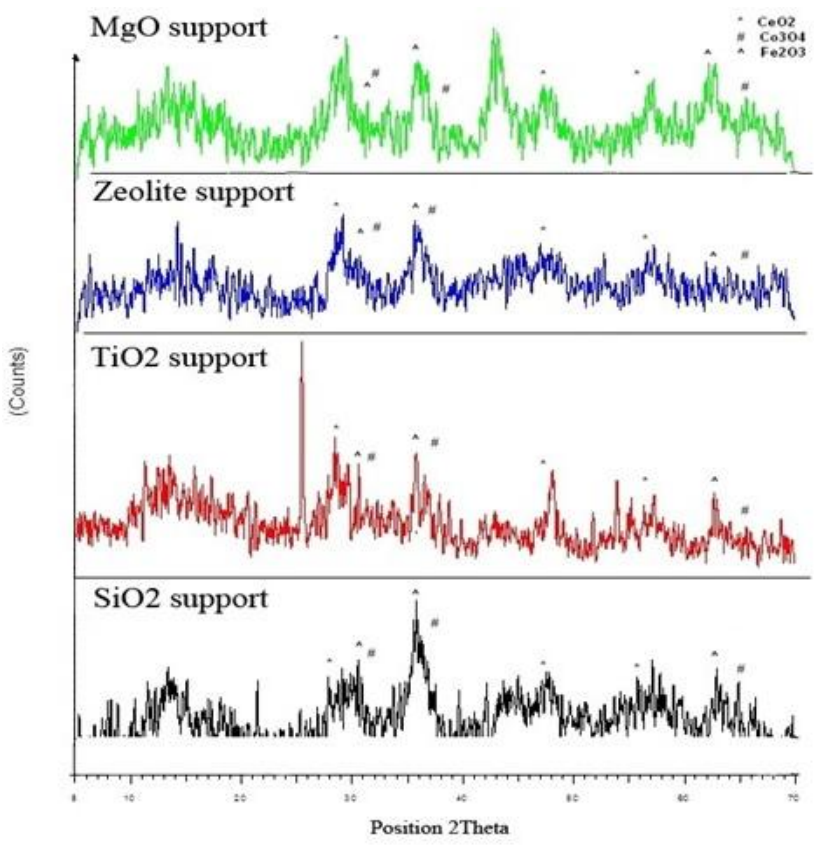

Fig. 2. XRD patterns of nanocatalyst synthesized with different supports $\left(\mathrm{MgO}\right.$, zeolite, $\left.\mathrm{TiO}_{2}, \mathrm{SiO}_{2}\right)$

Particle size of the synthesized nanocatalyst with different supports from XRD technique

\begin{tabular}{|c|c|c|}
\hline Type of support & Particle size from SEM, nm & Particle size from XRD, nm \\
\hline $\mathrm{SiO}_{2}$ & 32.6 & 2.7 \\
\hline $\mathrm{Zeolite}$ & 55.1 & 4.1 \\
\hline $\mathrm{MgO}$ & 53.7 & 4.1 \\
\hline $\mathrm{TiO}_{2}$ & 61.7 & 8.2 \\
\hline
\end{tabular}




\subsubsection{Scanning electron microscopy (SEM)}

Fig. 3 indicates the SEM images of nanocatalyst synthesized with different supports. The result shows that nanocatalyst with $\mathrm{SiO}_{2}$ support has the smaller particle size while the nanocatalyst with $\mathrm{TiO}_{2}$ support has larger particle size (Table 1). The SEM micrographs of samples show the spherical shape and uniform morphology of nanocatalysts. In comparison, the particle size obtained from SEM (Table 1) is larger than the average size obtained from XRD pattern. This is due to the effect of stronger interaction among particles such as van der Waals, which causes agglomeration [12].

\subsubsection{Temperature programmed reduction (TPR)}

The temperature-programmed reduction (TPR) technique was applied to illustrate the reducibility of nanocatalysts and distinguish the types of existing metal oxide species in the samples. Hydrogen TPR profiles of nanocatalysts synthesized with various supports are shown in Fig. 4. When using XRD technique the following phases of nanoparticles were obtained: $\mathrm{CeO}_{2}$ (cubic), $\mathrm{Co}_{3} \mathrm{O}_{4}$ (cubic), and $\mathrm{Fe}_{2} \mathrm{O}_{3}$ (rohombohedral). It has been reported that all metal oxidic phases indicate two reduction peaks including $\mathrm{Fe}_{2} \mathrm{O}_{3}$ at 605 and $623-873 \mathrm{~K}$, $\mathrm{Co}_{3} \mathrm{O}_{4}$ at 621 and $894 \mathrm{~K}$, ceria at 758 and $1073 \mathrm{~K}[13,14]$. The TPR profile shows that the nanocatalysts with different supports have four reduction peaks (A, B, C, and $\mathrm{D})$, which are indicated in Fig. 4. The first peak (A) is related to the reduction of $\mathrm{Fe}_{2} \mathrm{O}_{3}$ to $\mathrm{Fe}_{3} \mathrm{O}_{4}$ and $\mathrm{Co}_{3} \mathrm{O}_{4}$ to $\mathrm{CoO}$. The second peak $(\mathrm{B})$ is due to the surface reduction of $\mathrm{CeO}_{2}$ to $\mathrm{Ce}_{2} \mathrm{O}_{3}$ and $\mathrm{CoO}$ to $\mathrm{Co}^{0}$. The third shoulder peak (C) corresponds to the reduction of $\mathrm{Fe}_{3} \mathrm{O}_{4} \rightarrow \mathrm{FeO} \rightarrow \mathrm{Fe}^{0}$. The fourth reduction peak is attributed to bulk reduction of cerium by elimination of $\mathrm{O}^{-2}$ anions of the lattice $\mathrm{Ce}_{2} \mathrm{O}_{3} \rightarrow \mathrm{Ce}^{0}$ [15]. From Fig. 4 it is obvious that the catalyst with $\mathrm{SiO}_{2}$ support can facilitate the reduction process of the catalyst, because the reduction process begins and ends at lower temperature (A and D). These results indicate more reducibility of $\mathrm{SiO}_{2}$ support, due to stronger interaction between metal-support. There is a correlation with a nanocatalyst particle size and the interaction between the catalyst and the support. The smaller particle size, the stronger degree of interaction with support, which leads a lower reducibility.
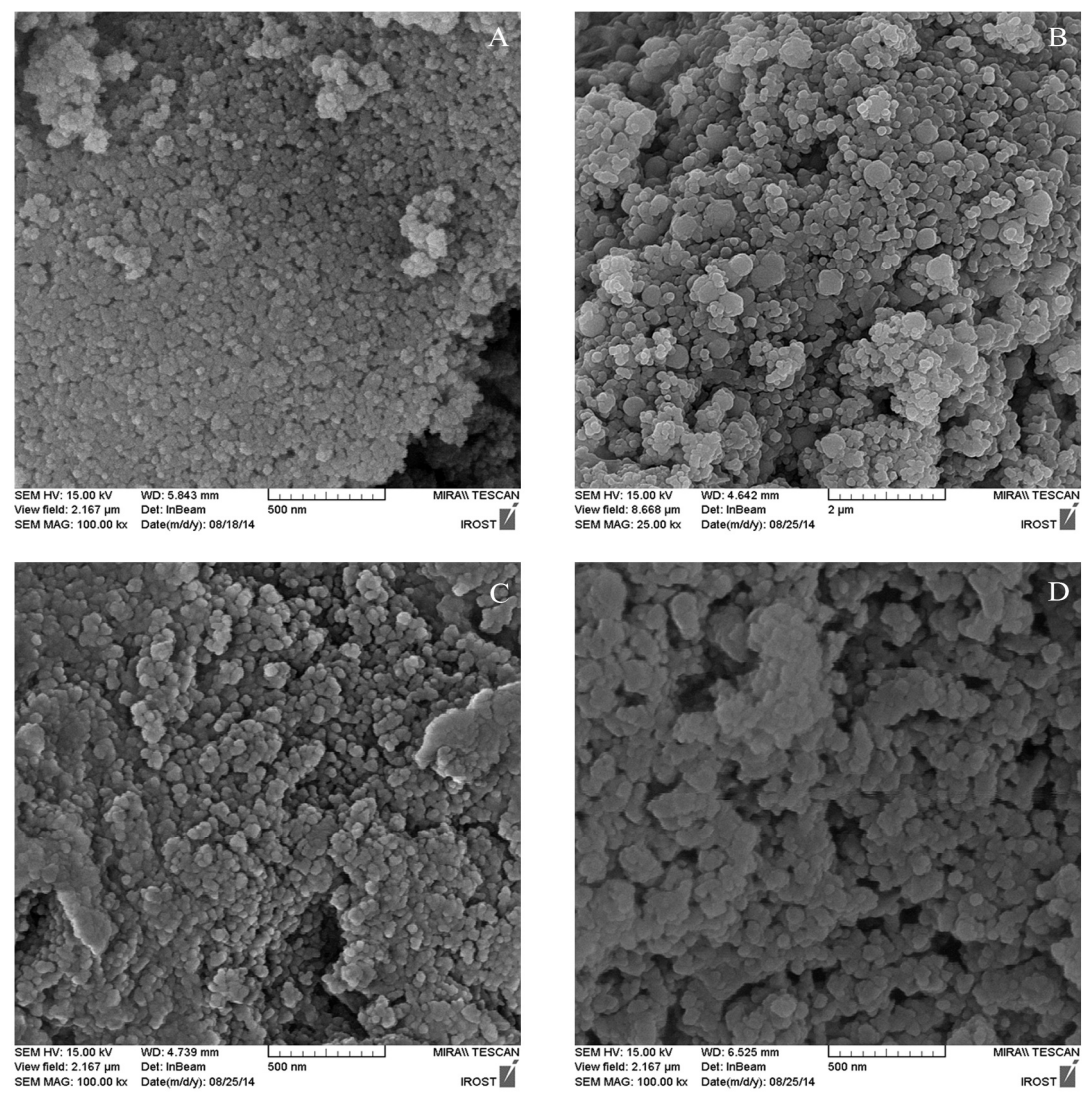

Fig. 3. SEM images of the synthesized nanocatalyst with different supports: $\mathrm{SiO}_{2}$ (a), zeolite (b), $\mathrm{MgO}(\mathrm{c})$ and $\mathrm{TiO}_{2}(\mathrm{~d})$ 


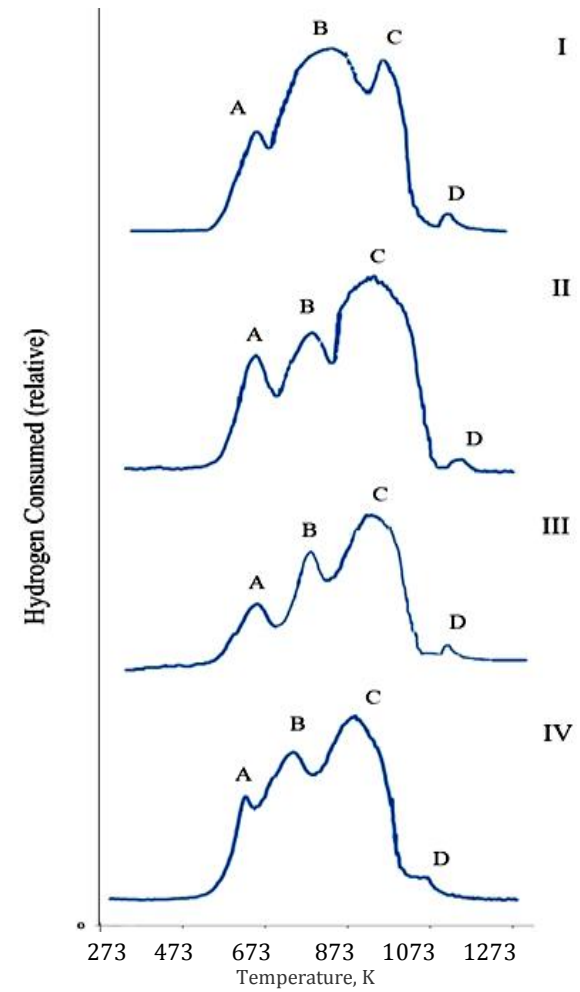

Fig. 4. TPR profiles of Fe-Co-Ce nanocatalyst synthesized with different supports: $\mathrm{MgO}$ (I), zeolite (II), $\mathrm{TiO}_{2}$ (III) and $\mathrm{SiO}_{2}$ (IV)

\subsection{Fischer-Tropsch Synthesis}

\subsubsection{Effect of operating conditions}

The Fischer-Tropsch synthesis produces a wide range of hydrocarbons, however distribution of products strongly depends on the operating conditions. The Fe-Co-Ce synthesized nanocatalyst was investigated under different operating conditions (e.g. $\mathrm{H}_{2} / \mathrm{CO}$ molar ratio, Red-GHSV, and Oprat-GHSV) in a fixed-bed reactor. A statistical model is proposed for olefin, paraffin, and methane in CO hydrogenation, as well as the optimization conditions are achieved due to higher selectivity towards light olefins and lower selectivity to paraffin and methane.

\subsubsection{Effect of $\mathrm{H}_{2} / \mathrm{CO}$ ratio in feeding gas}

The effect of $\mathrm{H}_{2} / \mathrm{CO}$ feed molar ratio is distinctive, which plays essential role straightly in reactivity and selectivity of FT synthesis. It has been reported that the termination reaction of paraffins is more desired than that of olefins in order to increase $\mathrm{H}_{2} / \mathrm{CO}$ molar feed ratio, which enhances the concentration of surface hydrogen. These results lead to increase in the selectivity to low molecular weight products [16]. The influence of $\mathrm{H}_{2} / \mathrm{CO}$ feed molar ratio in the range of 1:1, 2:1, 1:2, 3:1, 1:3, 4:1 and $1: 4$ on steady state condition under equal operating conditions $\left(\mathrm{GHSV}=3600 \mathrm{~h}^{-1}, P=200 \mathrm{kPa}, T=573 \mathrm{~K}\right)$ is demonstrated in Table 2.

Table 2

Experimental data obtained under operating and synthesis conditions

\begin{tabular}{|c|c|c|c|c|c|c|}
\hline $\begin{array}{l}\text { Type of } \\
\text { support }\end{array}$ & $\begin{array}{c}\text { Selectivity to } \\
\text { olefins, } \%\end{array}$ & $\begin{array}{l}\text { Selectivity to } \\
\text { paraffins, } \%\end{array}$ & $\begin{array}{l}\text { Selectivity } \\
\text { to } \mathrm{C}_{1}, \%\end{array}$ & Reduction GHSV, $\mathrm{h}^{-1}$ & $\begin{array}{c}\mathrm{H}_{2} / \mathrm{CO} \\
\text { Feeding gas }\end{array}$ & Operating GHSV, h \\
\hline no support & 14.81 & 18.41 & 31 & 3600 & 1 & 3600 \\
\hline no support & 27.65 & 21.75 & 34 & 3600 & 2 & 3600 \\
\hline no support & 6.58 & 14.89 & 28 & 3600 & $1 / 2$ & 3600 \\
\hline no support & 35.02 & 16.71 & 38.6 & 3600 & 3 & 3600 \\
\hline no support & 3.53 & 12.3 & 25 & 3600 & $1 / 3$ & 3600 \\
\hline no support & 43.05 & 11.99 & 36 & 3600 & 4 & 3600 \\
\hline no support & 1.8 & 11.95 & 24.4 & 3600 & $1 / 4$ & 3600 \\
\hline no support & 4.84 & 15.34 & 44.26 & 900 & 1 & 3600 \\
\hline no support & 7.76 & 16.31 & 38.5 & 1800 & 1 & 3600 \\
\hline no support & 11.75 & 17.01 & 32.5 & 2700 & 1 & 3600 \\
\hline no support & 19.55 & 22.43 & 32.54 & 5400 & 1 & 3600 \\
\hline no support & 14.34 & 17.81 & 31 & 3600 & 1 & 3600 \\
\hline no support & 26.26 & 11.67 & 39.7 & 3600 & 1 & 4200 \\
\hline no support & 31.97 & 7.68 & 43.4 & 3600 & 1 & 4800 \\
\hline no support & 32.52 & 6.54 & 42.76 & 3600 & 1 & 5400 \\
\hline no support & 30.01 & 6.97 & 38.7 & 3600 & 1 & 6000 \\
\hline no support & 24.58 & 7.11 & 31.48 & 3600 & 1 & 6600 \\
\hline $\mathrm{MgO}$ & 25.12 & 10.97 & 39.8 & 3600 & 1 & 3600 \\
\hline $\mathrm{SiO}_{2}$ & 30.54 & 11.3 & 42.6 & 3600 & 1 & 3600 \\
\hline $\mathrm{TiO}_{2}$ & 28.75 & 17.02 & 44.5 & 3600 & 1 & 3600 \\
\hline zeolite & 22.29 & 26.5 & 39.7 & 3600 & 1 & 3600 \\
\hline
\end{tabular}




\section{Selectivity to hydrocarbon produced when using different supports of $\mathrm{Fe}-\mathrm{Co}-\mathrm{Ce}$ nanocatalyst and predicted values by RSM}

\begin{tabular}{|c|c|c|c|c|c|c|}
\hline \multirow{2}{*}{$\begin{array}{l}\text { Type of } \\
\text { support }\end{array}$} & \multicolumn{3}{|c|}{ Response (experimental) } & \multicolumn{3}{|c|}{ Response (predicted by RSM) } \\
\hline & $\begin{array}{c}\text { Selectivity to } \\
\text { olefins, } \%\end{array}$ & $\begin{array}{c}\text { Selectivity to } \\
\text { paraffins, } \%\end{array}$ & $\begin{array}{c}\text { Selectivity to } \\
\mathrm{C}_{1}, \%\end{array}$ & $\begin{array}{c}\text { Selectivity to } \\
\text { olefins, \% }\end{array}$ & $\begin{array}{c}\text { Selectivity to } \\
\text { paraffins, } \%\end{array}$ & $\begin{array}{c}\text { Selectivity to } \\
\mathrm{C}_{1}, \%\end{array}$ \\
\hline no support & 14.81 & 18.41 & 31 & 14.3064 & 17.8147 & 30.8881 \\
\hline no support & 27.65 & 21.75 & 34 & 27.1673 & 20.7501 & 35.8598 \\
\hline no support & 6.58 & 14.89 & 28 & 6.5633 & 14.4245 & 27.2524 \\
\hline no support & 35.02 & 16.71 & 38.6 & 36.5281 & 18.5585 & 37.7649 \\
\hline no support & 3.53 & 12.3 & 25 & 3.7313 & 12.9798 & 25.8416 \\
\hline no support & 43.05 & 11.99 & 36 & 42.3886 & 11.2399 & 36.6036 \\
\hline no support & 1.8 & 11.95 & 24.4 & 2.3636 & 12.2487 & 25.1470 \\
\hline no support & 4.84 & 15.34 & 44.26 & 4.7169 & 15.7077 & 44.4775 \\
\hline no support & 7.76 & 16.31 & 38.5 & 8.1443 & 15.8080 & 37.8024 \\
\hline no support & 11.75 & 17.01 & 32.5 & 11.3407 & 16.5103 & 33.2726 \\
\hline no support & 19.55 & 22.43 & 32.54 & 19.5450 & 22.2297 & 32.5550 \\
\hline no support & 14.34 & 17.81 & 31 & 14.3064 & 17.8147 & 30.8881 \\
\hline no support & 26.26 & 11.67 & 39.7 & 24.8876 & 12.1300 & 39.0323 \\
\hline no support & 31.97 & 7.68 & 43.4 & 31.1529 & 8.2749 & 43.1263 \\
\hline no support & 32.52 & 6.54 & 42.76 & 33.1020 & 6.2494 & 43.1699 \\
\hline no support & 30.01 & 6.97 & 38.7 & 30.7351 & 6.0536 & 39.1633 \\
\hline no support & 24.58 & 7.11 & 31.48 & 24.0521 & 7.6875 & 31.1064 \\
\hline $\mathrm{MgO}$ & 25.12 & 10.97 & 39.8 & 25.2213 & 11.7616 & 39.2598 \\
\hline $\mathrm{SiO}_{2}$ & 30.54 & 11.3 & 42.6 & 30.1676 & 11.2535 & 43.5534 \\
\hline $\mathrm{TiO}_{2}$ & 28.75 & 17.02 & 44.5 & 29.1453 & 16.2905 & 43.7690 \\
\hline zeolite & 22.29 & 26.5 & 39.7 & 22.1544 & 26.8725 & 39.9066 \\
\hline
\end{tabular}

\subsubsection{Effect of reduction and operating GHSV}

GHSV is an operating parameter with a crucial importance, which affects the catalytic performance of nanocatalyst. Gas hourly space velocity or gas residence time is defined as a total volumetric feed flow rate of synthesis gas per unit of bed volume. The effects of reduction and operating GHSV in the range of 900,1800 , 2700 and $5400 \mathrm{~h}^{-1}$ and $3600,4200,4800,5400,6000$ and $6600 \mathrm{~h}^{-1}$, respectively, on the catalyst selectivity and CO conversion under operating conditions $\left(\mathrm{H}_{2} / \mathrm{CO}=1, P=\right.$ $=200 \mathrm{kPa}, T=573 \mathrm{~K}$ ) are reported in Tables 2 and 3 . The increase in space velocity leads to the decrease in $\mathrm{CO}$ conversion and the resistant time of both reactants and products in the reactor.

\subsubsection{Optimizing conditions for products selectivity}

Recently a lot of researches have been carried out on the effect of operating GHSV in a catalytic performance. Feyzi et al. [5] reported the optimal operating GHSV $=2000 \mathrm{~h}^{-1}$ in order to achieve higher light olefins $\mathrm{C}_{2}-\mathrm{C}_{4}$ selectivity. Arsalanfar et al. [6] investigated the effect of various space velocities on catalytic performance of Fe-Co-Mn catalyst supported by
$\mathrm{MgO}$ prepared using co-precipitation method. Some articles reported the effect of $\mathrm{H}_{2} / \mathrm{CO}$ feed ratio on catalytic performance, e.g. Atashiet et al. [17] illustrated the effect of operating conditions on selectivity of $\mathrm{Fe}-\mathrm{Co}-\mathrm{Mn} / \mathrm{MgO}$ at high temperature for $\mathrm{CO}$ hydrogenation.

The influence of operating conditions including Red-GHSV, inlet $\mathrm{H}_{2} / \mathrm{CO}$, Oprat-GHSV, and Type-support on selectivity of Fe-Co-Ce nanocatalyst in the FischerTropsch synthesis under operating conditions (GHSV = $\left.=3600 \mathrm{~h}^{-1}, \mathrm{H}_{2} / \mathrm{CO}=1, P=200 \mathrm{kPa}, T=573 \mathrm{~K}\right)$ is illustrated as a statistical model, is represented in Table 2. The achieved results from experimental and predicted data by RSM are presented in Table 3. According to indicative variables, selectivity models for olefin, paraffin, and methane are obtained. The regression coefficients achieved by RSM are indicated in Table 4 . The goal of this study is to maximize olefin and minimize paraffin and methane towards zero targets and to optimize data of single and three objectives responses (Table 5).

Single objective optimization of olefin, paraffin, and methane is depicted in Figs. 5-7. As well as, three objectives optimization for maximizing olefin and minimizing paraffin and methane obtained at Red-GHSV = $=4156.52 \mathrm{~h}^{-1}$, Oprat-GHSV $=6600 \mathrm{~h}^{-1}, \mathrm{H}_{2} / \mathrm{CO}=4$, and Type-support $=$ no support, is shown in Fig. 8 . 
Table 4

Regression coefficients of the RSM modeling for the selectivity response

\begin{tabular}{|c|c|c|c|c|c|c|c|c|c|}
\hline \multirow{2}{*}{ Terms } & \multicolumn{3}{|c|}{ Selectivity to olefins, $\%$} & \multicolumn{3}{c|}{ Selectivity to paraffins, $\%$} & \multicolumn{3}{c|}{ Selectivity to $\mathrm{C}_{1}, \%$} \\
\cline { 2 - 11 } & SE coef. & $T$-value & $P$-value & SE coef. & $T$-value & $P$-value & SE coef. & $T$-value & $P$-value \\
\hline Constant & 0.800 & 76.60 & 0.000 & 1.01 & 2.65 & 0.021 & 1.14 & 54.94 & 0.000 \\
\hline Red-GHSV & 0.448 & 16.55 & 0.000 & 0.568 & 5.74 & 0.000 & 0.638 & -9.34 & 0.000 \\
\hline $\mathrm{H}_{2} / \mathrm{CO}$ & 0.369 & 54.26 & 0.000 & 0.468 & -1.08 & 0.302 & 0.525 & 10.91 & 0.000 \\
\hline Operate-GHSV & 0.345 & 14.14 & 0.000 & 0.437 & -11.59 & 0.000 & 0.491 & 0.22 & 0.828 \\
\hline Type-support & 0.359 & 10.93 & 0.000 & 0.455 & 9.95 & 0.000 & 0.511 & 8.82 & 0.000 \\
\hline Red-GHSV·Red-GHSV & 0.610 & -1.18 & 0.260 & 0.773 & 2.43 & 0.031 & 0.868 & 7.72 & 0.000 \\
\hline $\mathrm{H}_{2} / \mathrm{CO} \cdot \mathrm{H}_{2} / \mathrm{CO}$ & 0.685 & -8.98 & 0.000 & 0.869 & -10.38 & 0.000 & 0.976 & -5.52 & 0.000 \\
\hline Oprat-GHSV·Oprat-GHSV & 0.616 & -21.90 & 0.000 & 0.781 & 7.32 & 0.000 & 0.877 & -14.43 & 0.000 \\
\hline \multirow{3}{*}{ Type-support·Type-support } & 0.656 & -18.19 & 0.000 & 0.832 & 13.33 & 0.000 & 0.935 & -8.73 & 0.000 \\
\cline { 2 - 9 } & \multicolumn{3}{|c|}{$R^{2}=99.63 \%$} & \multicolumn{3}{c}{$R^{2}=98.28 \%$} & \multicolumn{3}{c}{$R^{2}=98.33 \%$} \\
$R_{a d j}^{2}=98.17 \%$ & $R_{a d j}^{2}=97.14 \%$ & \multicolumn{3}{c}{$R_{a d j}^{2}=97.21 \%$} \\
\hline
\end{tabular}

Table 5

Optimization results for single and three objectives

\begin{tabular}{|c|c|c|c|c|c|c|c|c|}
\hline \multicolumn{2}{|c|}{} & $\begin{array}{c}\text { Reduction } \\
\text { GHSV, } \mathrm{h}^{-1}\end{array}$ & $\begin{array}{c}\mathrm{H}_{2} / \mathrm{CO} \\
\text { Feeding gas }\end{array}$ & $\begin{array}{c}\text { Operating } \\
\mathrm{GHSV}, \mathrm{h}^{-1}\end{array}$ & $\begin{array}{c}\text { Type of } \\
\text { support }\end{array}$ & $\begin{array}{c}\text { Selectivity } \\
\text { to olefins, } \\
\%\end{array}$ & $\begin{array}{c}\text { Selectivity to } \\
\text { paraffins, } \%\end{array}$ & $\begin{array}{c}\text { Selectivity } \\
\text { to } \mathrm{C}_{1}, \%\end{array}$ \\
\hline $\begin{array}{c}\text { Single } \\
\text { objective }\end{array}$ & $\begin{array}{c}\text { Maximize } \\
\text { olefins }\end{array}$ & 5400 & 4 & 5357.58 & $\mathrm{SiO}_{2}$ & 43.05 & 0 & 0 \\
\cline { 2 - 9 } & $\begin{array}{c}\text { Minimize } \\
\text { paraffins }\end{array}$ & 1218.18 & 4 & 5751.52 & $\mathrm{MgO}$ & 0 & 6.54 & 0 \\
\cline { 2 - 9 } & $\begin{array}{c}\text { Minimize } \\
\mathrm{C}_{1}\end{array}$ & 4172.73 & 0.25 & 3600 & $\begin{array}{c}\text { no } \\
\text { support }\end{array}$ & 0 & 0 & 25 \\
\hline $\begin{array}{c}\text { Three } \\
\text { objectives }\end{array}$ & $\begin{array}{c}\text { Maximize } \\
\text { olefins and } \\
\text { minimize } \\
\text { paraffins } \\
\text { and } \mathrm{C}_{1}\end{array}$ & 4156.52 & 4 & 6600 & $\begin{array}{c}\text { no } \\
\text { support }\end{array}$ & 43.05 & 6.54 & 25 \\
\hline
\end{tabular}

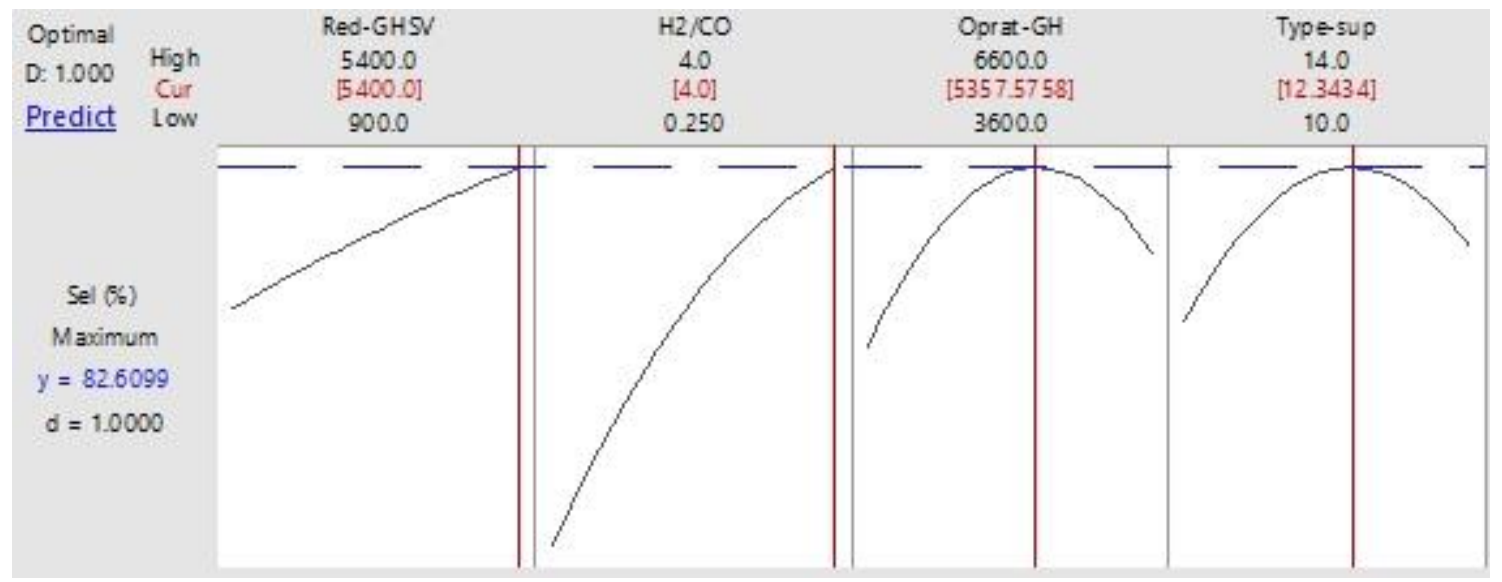

Fig. 5. The single objective optimization obtained to maximize olefin selectivity using Minitab software 


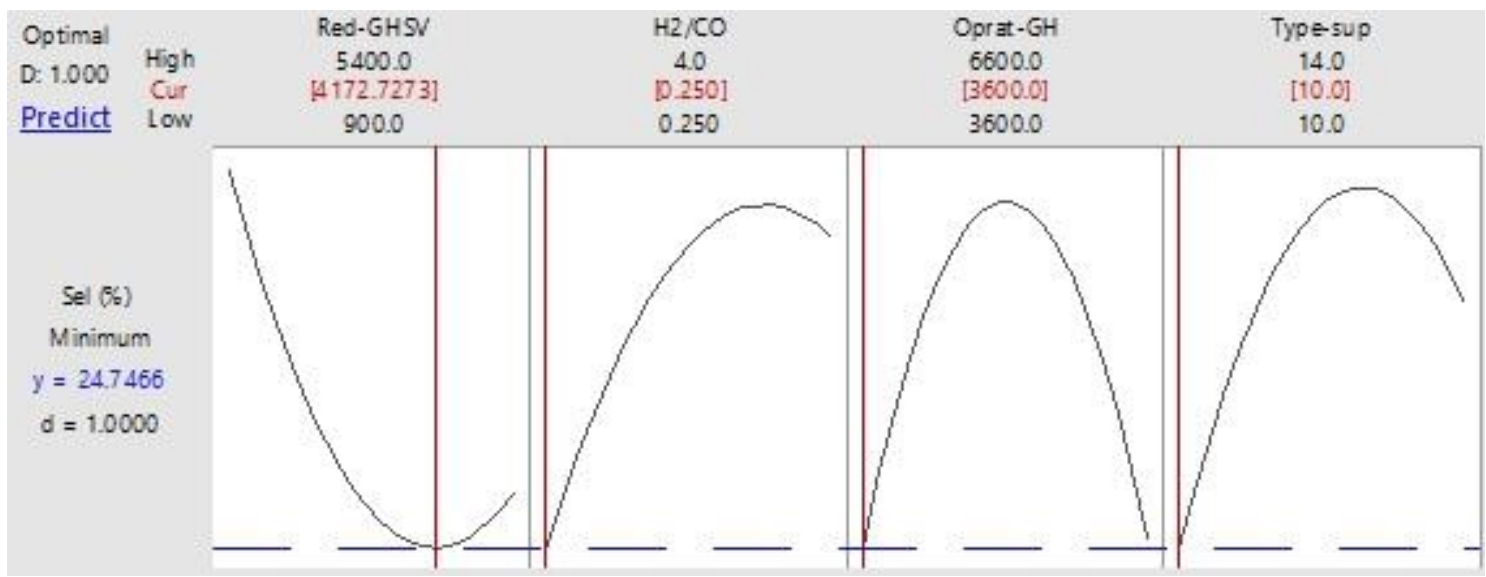

Fig. 6. The single objective optimization obtained to minimize $C_{1}$ selectivity using Minitab software

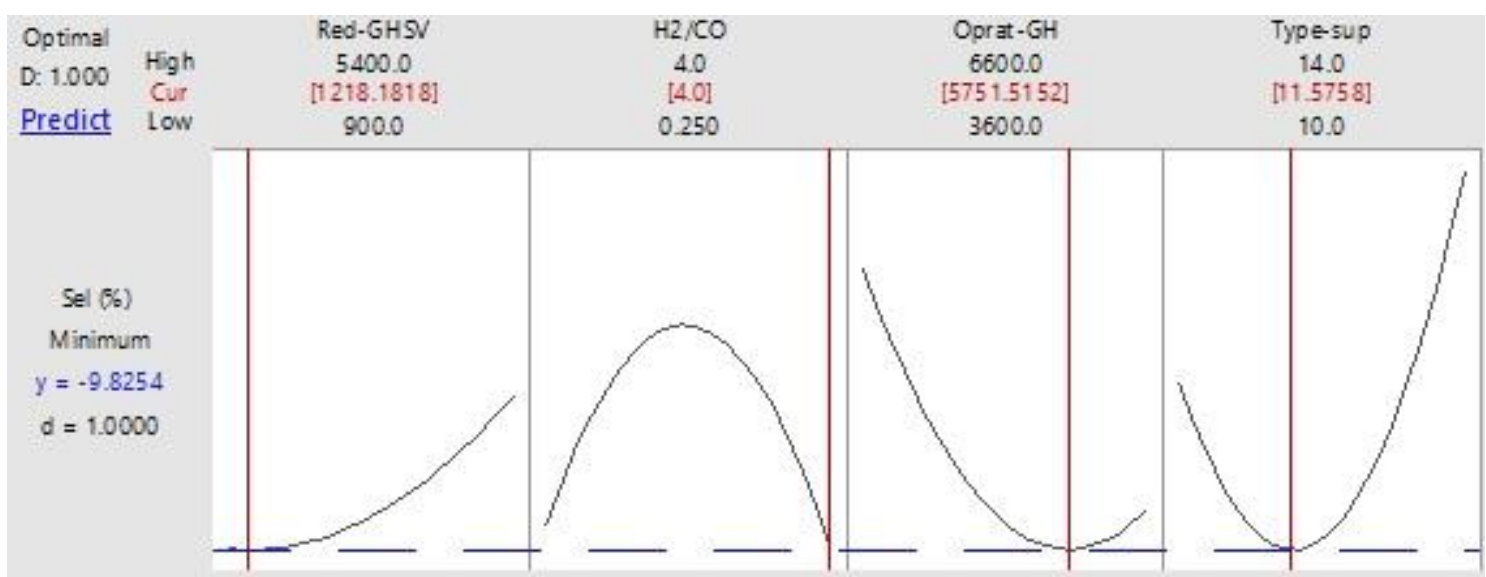

Fig. 7. The single objective optimization obtained to minimize paraffin selectivity using Minitab software

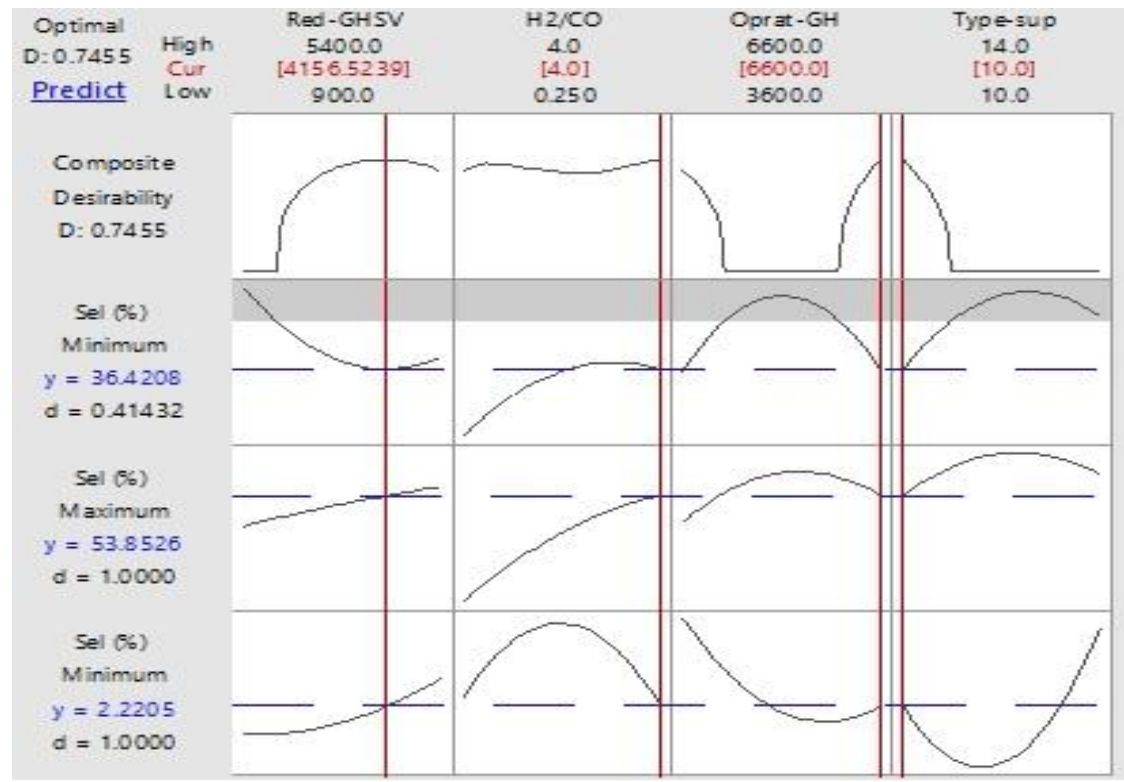

Fig. 8. Three objectives optimization obtained to maximize olefin selectivity and minimize paraffins and $\mathrm{C}_{1}$ using Minitab software 


\subsubsection{Selectivity to olefins}

Changes in olefins selectivity depending on various operating conditions and different supports are shown in Fig. 9. It is observed that by increasing $\mathrm{H}_{2} / \mathrm{CO}$ molar ratio with zeolite as the support, the olefin selectivity increases with the increase in both operating and reduction GHSV. The highest olefin selectivity was achieved by enhancing the Red-GHSV, at high Oprat-GHSV and with $\mathrm{SiO}_{2}$ as the support. A parabola plot with a maximum shows that at moderate operating GHSV and with $\mathrm{SiO}_{2}$ as the support the highest selectivity towards olefin is achieved.
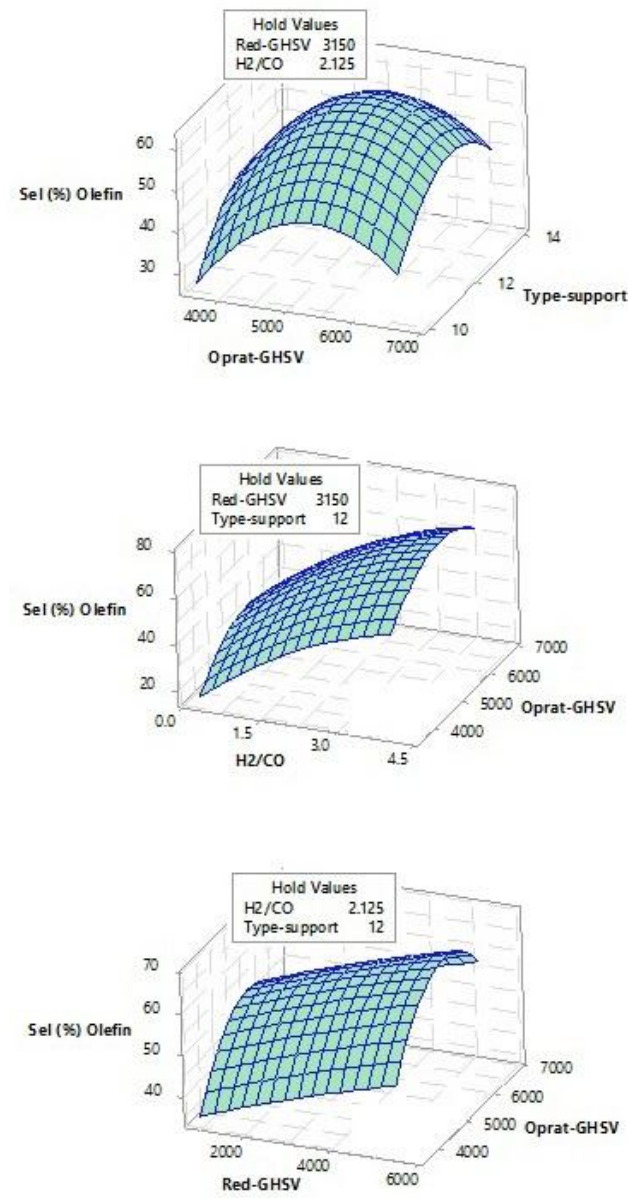

Fig. 9. Three-dimensional response surface plot of Red-GHSV, Oprat-GHSV, $\mathrm{H}_{2} / \mathrm{CO}$ and Type-support on selectivity to olefins

\subsection{Selectivity to paraffins}

Selectivity to paraffins changes depending on various operating conditions and different supports, is shown in Fig. 10. It can be seen from the minimum peak of parabola plot that the selectivity to paraffins is the highest at lower Oprat-GHSV, and higher Red-GHSV, with zeolite as the support. However, at average value of
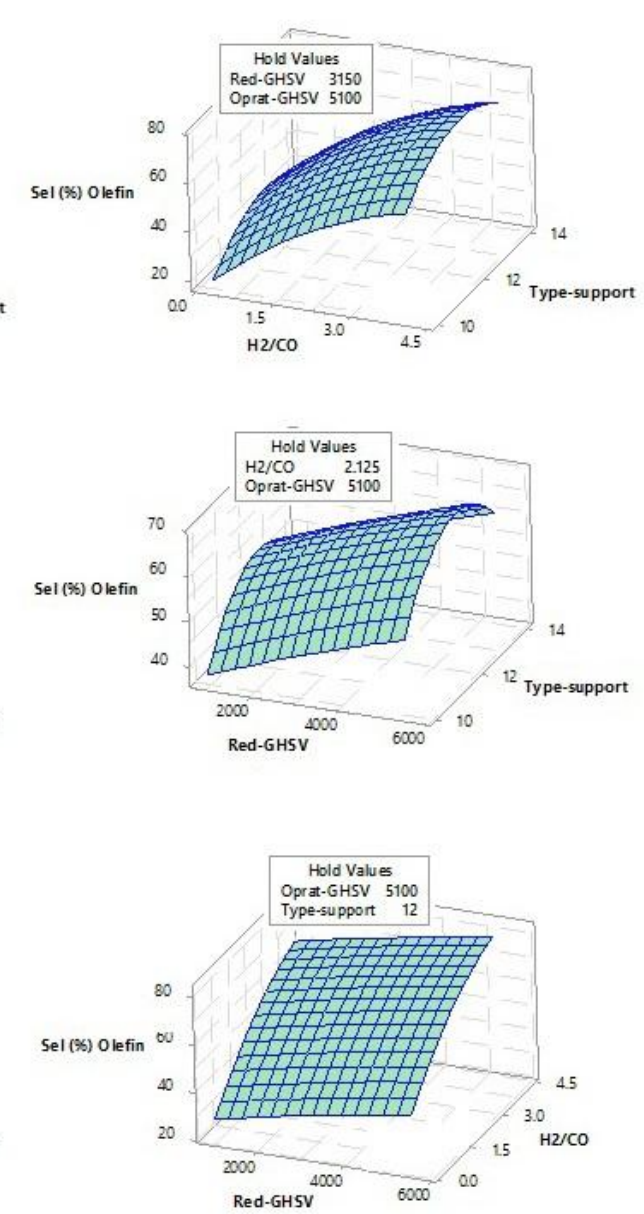

Selectivity model for olefins is given by Eq. (6):

Sel $(\%)$ olefins $=-606.8+0.004193$ Red-GHSV + $+18.111 \mathrm{H}_{2} / \mathrm{CO}+0.06439$ Oprat-GHSV + +73.59 Type-support -0.000000 Red-GHSV·Red-GHSV $-1.750 \mathrm{H}_{2} / \mathrm{CO}^{-} \mathrm{H}_{2} / \mathrm{CO}-$ 0.000006 Oprat-GHSV·Oprat-GHSV -2.984 Type-support-Type-support

The statistical model of olefin indicates that GHSV of reduction (Red-GHSV-Red-GHSV) is the most important factor due to maximizing olefins. The single optimizing data to maximaze olefins selectivity are achieved at Red-GHSV $=5400 \mathrm{~h}^{-1}$, Oprat-GHSV $=$ $=5357.58 \mathrm{~h}^{-1}, \mathrm{H}_{2} / \mathrm{CO}=4$, and Type-support $=\mathrm{SiO}_{2}$.

$\mathrm{H}_{2} / \mathrm{CO}$ with zeolite as the support, and at higher RedGHSV and lower Oprat-GHSV, the selectivity to paraffins is a higher value. The final statistical model for selectivity to paraffins is presented by Eq. (7):

$$
\begin{gathered}
\text { Sel }(\%) \text { paraffins }=446.2-0.000892 \text { Red-GHSV }+ \\
+10.63 \mathrm{H}_{2} / \mathrm{CO}-0.02930 \text { Oprat-GHSV }- \\
-64.28 \text { Type-support }+0.000000 \text { Red-GHSV-Red-GHSV - }
\end{gathered}
$$


$-2.563 \mathrm{H}_{2} / \mathrm{CO} \cdot \mathrm{H}_{2} / \mathrm{CO}+0.000003$ Oprat-GHSV-Oprat-GHSV + 2.773 Type-support-Type-support

On the base of statistical model, it can be seen that the type of support with the higher coefficient of Type-
support-Type-support have the prominent effect on minimizing the paraffin selectivity. According to single optimizing result, the minimizing of paraffin is achieved at Red-GHSV $=1218.18 \mathrm{~h}^{-1}$, Oprat-GHSV $=5751.52 \mathrm{~h}^{-1}$, $\mathrm{H}_{2} / \mathrm{CO}=4$, and Type-support $=\mathrm{MgO}$.
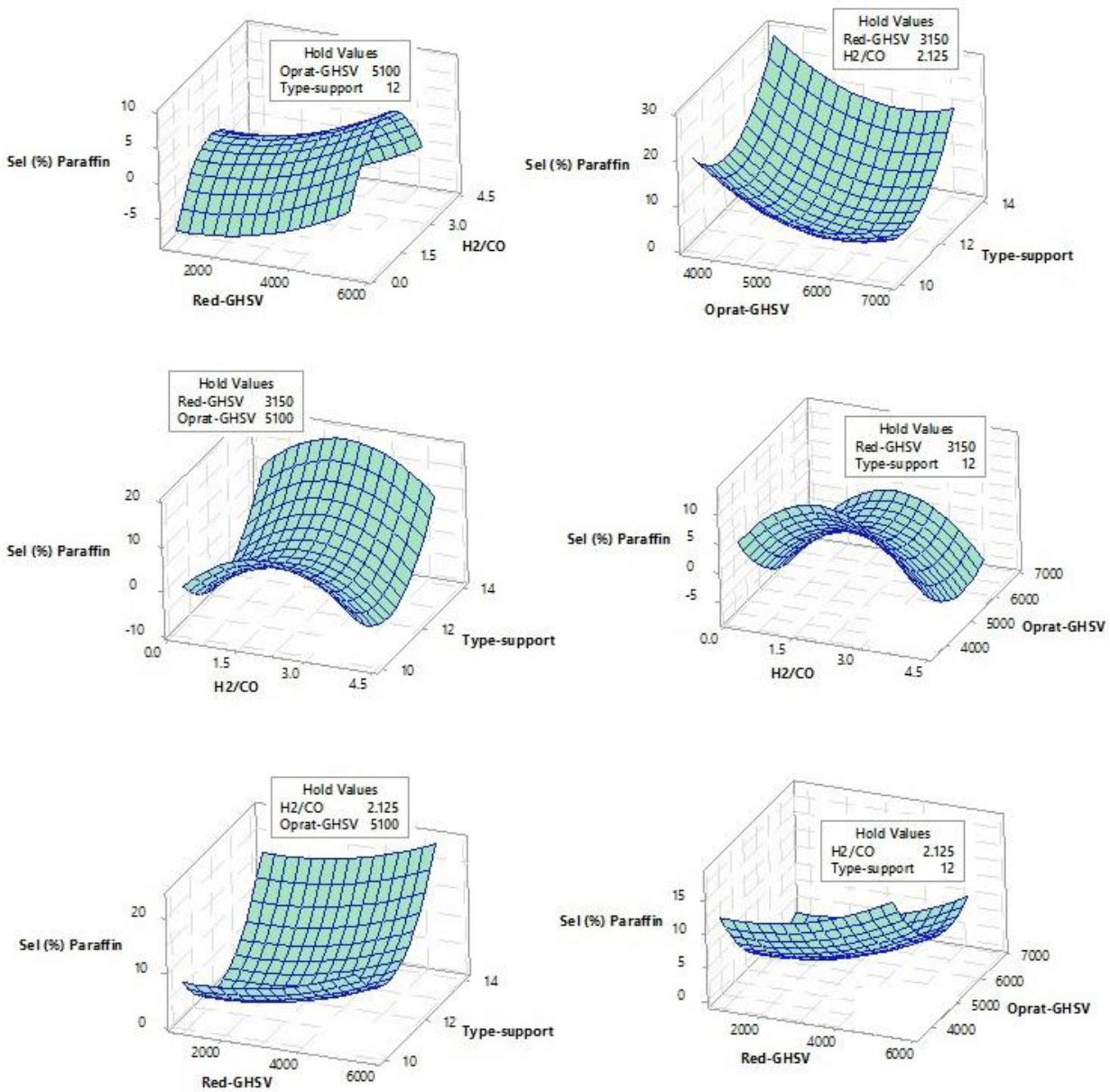

Fig. 10.Three-dimensional response surface plot of Red-GHSV, Oprat-GHSV, $\mathrm{H}_{2} / \mathrm{CO}$, and Type-support effects on selectivity to paraffins

\subsubsection{Selectivity to $\mathbf{C}_{1}$}

Changes in selectivity to methane depending on various operating conditions and different supports are shown in Fig. 11. It can be seen from a maximum parabola plot that the maximum methane selectivity is obtained by rising in $\mathrm{H}_{2} / \mathrm{CO}$ molar ratio at moderate Oprat-GHSV, lower Red-GHSV, and $\mathrm{SiO}_{2}$ as a support. The statistical selectivity model of methane is presented by Eq. (8):

$$
\begin{aligned}
& \text { Sel }(\%) \mathrm{C}_{1}=-396.7-0.01099 \text { Red-GHSV + } \\
& +9.57 \mathrm{H}_{2} / \mathrm{CO}+0.05745 \text { Oprat-GHSV }+
\end{aligned}
$$

$$
\begin{gathered}
+51.19 \text { Type-support }+0.000001 \text { Red-GHSV } \cdot \text { Red-GHSV }- \\
-\quad 1.533 \mathrm{H}_{2} / \mathrm{CO} \cdot \mathrm{H}_{2} / \mathrm{CO}-0.000006 \text { Oprat- } \\
\text { GHSV·Oprat-GHSV } \\
+\quad-2.039 \text { Type-support-Type-support }
\end{gathered}
$$

The obtained selectivity model for methane shows that Red-GHSV with the positive coefficient value of Red-GHSV-Red-GHSV has the significant effect in minimizing methane. Therefore, with the purpose of minimizing methane, the conditions are: Red-GHSV $=$ $=4172.73 \mathrm{~h}^{-1}$, Oprat-GHSV $=3600 \mathrm{~h}^{-1}, \mathrm{H}_{2} / \mathrm{CO}=0.25$, and Type-support $=$ no support. 

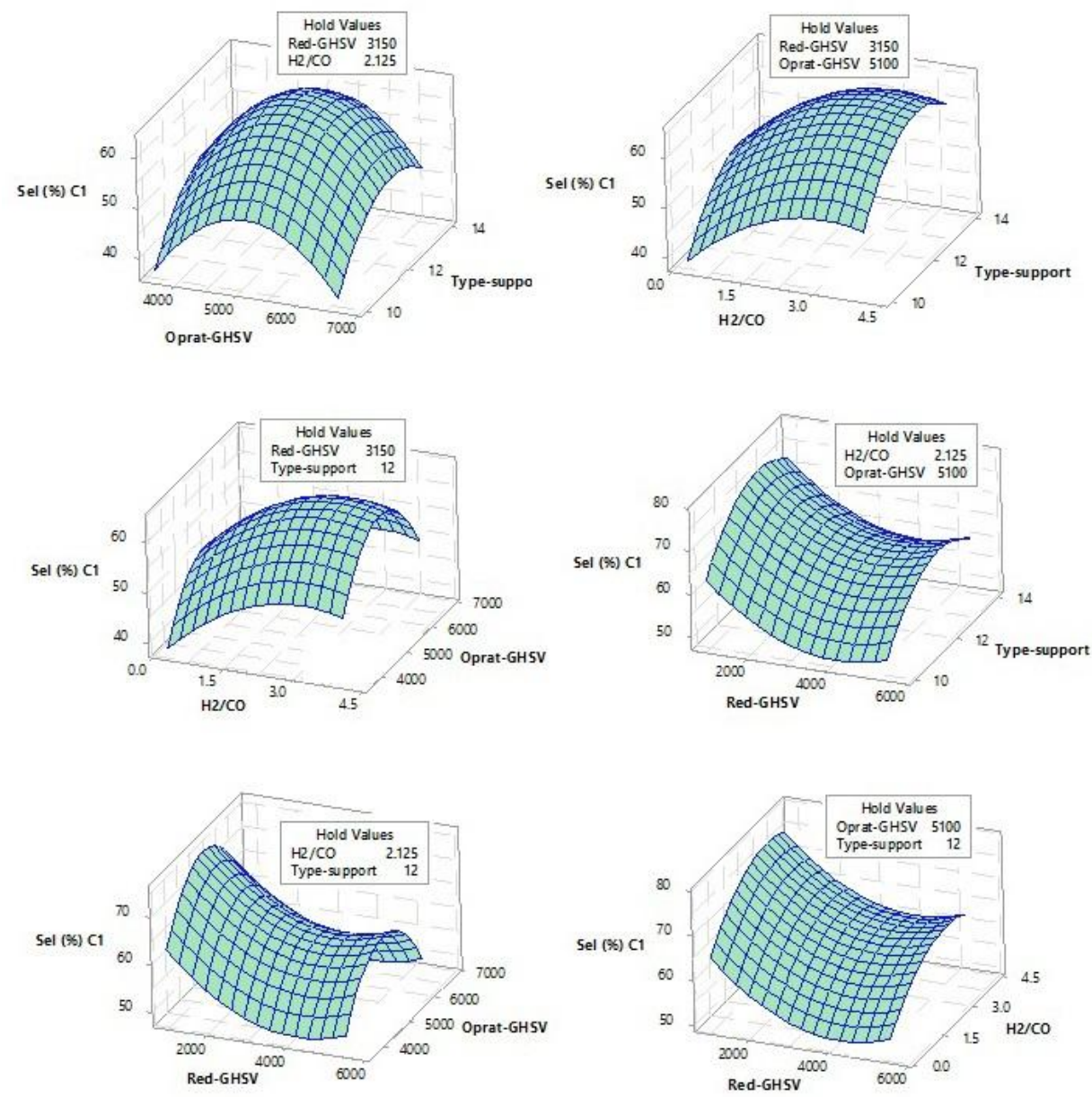

Fig. 11.Three-dimensional response surface plot of Red-GHSV, Oprat-GHSV, $\mathrm{H}_{2} / \mathrm{CO}$, and Type-support effects on selectivity to $\mathrm{C}_{1}$

\section{Conclusions}

In the present work, the statistical model of three responses is investigated according to operating variables and the effect of various supports including $\mathrm{MgO}$, zeolite, $\mathrm{TiO}_{2}$ and $\mathrm{SiO}_{2}$ by means of response surface methodology (RSM). The selectivity and catalytic performance of solvothermally prepared $\mathrm{Fe}-\mathrm{Co}-\mathrm{Ce}$ nanocatalysts toward olefins were illustrated in a fixed-bed reactor. Responses selectivity models for variables such as Red-GHSV, Inlet $\mathrm{H}_{2} / \mathrm{CO}$, Operat-GHSV, and Type-support were optimized with the goal of maximizing olefins. The single selectivity model for maximizing olefins, minimizing paraffins and methane indicates that Red-GHSV-Red-GHSV, Typesupport.Type-support, Red-GHSV-Red-GHSV, are the prominent factors respectively. The results of three objectives optimization to maximizing olefins, minimizing paraffins and methane were obtained at Red-GHSV = $=156.52 \mathrm{~h}^{-1}$, Oprat-GHSV $=6600 \mathrm{~h}^{-1}, \mathrm{H}_{2} / \mathrm{CO}=4$, and
Type-Support $=$ without support. The variations of particle size, morphology and reducibility were investigated by XRD, SEM and TPR analyses. The TPR profiles indicate that nanocatalyst with $\mathrm{SiO}_{2}$ support has the lower initial and final temperature of reduction.

\section{Acknowledgments}

The authors would like to thank the Ministry of Science \& Research, Research Department of Sistan \& Baluchestan University, as well as Iranian National Petrochemical Company (INPC) for financial supports.

\section{References}

[1] Zhyznevskiy V., Gumenetskiy V., Matskiv O., Shyshchak O.: Chem. Chem. Technol., 2013, 7, 15. https://doi.org/10.23939/chcht07.01.015

[2] Babyak L., Matsyak O., Shevchuk V.: Chem. Chem. Technol., 2011, 5, 95. https://doi.org/10.23939/chcht05.01.095 
[3] Babyak L., Matsyak O., Shevchuk V. et al.: Chem. Chem. Technol., 2009, 3, 305.

[4] Pielichowski J., Kowalski G., Zaikov G.: Chem. Chem. Technol., 2011, 5, 303. https://doi.org/10.23939/chcht05.03.303 [5] Feyzi M., Yaghobi N., Eslamimanesh V.: Mater. Res. Bull., 2015, 72, 143.

https://doi.org/doi:10.1016/j.materresbull.2015.07.039

[6] Arsalanfar M., Mirzaei A., Bozorgzadeh H., Atashi H.: J. Ind. Eng. Chem, 2012, 18, 2092.

https://doi.org/10.1016/j.jiec.2012.06.003

[7] Jacobs G., Das T., Zhang Y. et al.: Appl. Catal. A, 2002, 233, 263. https://doi.org/10.1016/S0926-860X(02)00195-3

[8] Atashi H., Rezaeian F.: Int. J. Hydrogen. Energ., 2017, 42, 15497. https://doi.org/10.1016/j.ijhydene.2017.04.224

[9] Sun Y., Wei J., Ping Zhang J., G. Yang: J. Nat. Gas. Sci. Eng., 2016, 28, 173. https://doi.org/10.1016/j.jngse.2015.11.008

[10] Gunaraj V., Murugan N.: J. Mater. Process. Technol., 1999, 88, 266. https://doi.org/10.1016/S0924-0136(98)00405-1

[11] Tauster S., Fung S., Baker R., Horsley J.: Science, 1981, 211, 1121. https://doi.org/10.1126/science.211.4487.1121

[12] Peddis D., Jonsson P., Laureti S., Varvaro G.: Front. Nanosci., 2014, 6, 129. https://doi.org/10.1016/B978-0-08-098353-0.00004-X [13] Khan A., Smimiotis P.: J. Mol. Catal. A, 2008, 280, 43. https://doi.org/10.1016/j.molcata.2007.10.022

[14] Davies K., Wells S., Charles S.: J. Magn. Magn. Mater., 1993, 122, 24. https://doi.org/10.1016/0304-8853(93)91031-2

[15] De Rivas B., Gutierrez-Ortiz J., Lopez-Fonseca R., GonzalezVelasco J.: Appl. Catal. A, 2006, 314, 54.

https://doi.org/10.1016/j.apcata.2006.08.005
[16] Madon R., Iglesia E.: J. Catal., 1993, 139, 576 https://doi.org/10.1006/jcat.1993.1051

[17] Atashi H., Razmjooei S., Khorashadizadeh M. et al.: J. Taiwan Inst. Chem. Eng., 2015, 54, 83 .

https://doi.org/10.1016/j.jtice.2015.03.017

Received: May 15, 2019 / Revised: November 15, 2019 / Accepted: December 19, 2019

\section{МОДЕЛЮВАННЯ РЕЖИМУ ПРОЦЕСУ І НОСІЇВ КАТАЛІЗАТОРА Fе-Со-Се ТА ОПТИМІЗАЦІЯ СЕЛЕКТИВНОСТІ ЛЕГКИХ ОЛЕФІНІВ ПРИ СИНТЕЗІ ФІШЕРА-ТРОПША}

Анотація. Досліджено вплив чинників (Red-GHSV, $\mathrm{H}_{2} / \mathrm{CO}$, Oprat-GHSV) та різних носіїв нанокаталізатора $\mathrm{Fe}$-Co-Ce на перебіг синтезу Фішера-Тропиа. 3 метою одержання вищоі селективності за олефінами при синтезі застосована статистична модель з методологією поверхневої реакиії, яка вказує на взаєммний вплив чинників один на одного. Визначено умови, за яких оптимізуються три чинники з метою максимізаиії олефінів та мінімізації парафінів і метану. Синтезовані нанокаталізатори з різними носіями досліджено методами дифракиійного рентгенівського аналізу, скануючої мікроскопії та термопрограмованого відновлення.

Ключові слова: моделювання, режсии прочесу, нанокаталізатор Fe-Co-Ce, носій, оптимізачія, синтез Фімера-Тропиа. 